\title{
Influence of male on estrus behavior, estradiol and progesterone release and puberty onset on prepubertal Saanen goats
}

\section{Influência do reprodutor sobre o comportamento de estro, liberação de estrógeno, progesterona e início da puberdade em cabras Saanen pré-puberes}

\author{
Laurinda Augusto $^{1}$; Alice Deleo Rodrigues ${ }^{1}$; Giovana Krempel Fonseca Merighe ${ }^{2}$; \\ Sandra Aparecida de Oliveira' ${ }^{2}$; Gabriela Facholi Bomfim ${ }^{1}$; João Alberto Negrão ${ }^{3 *}$
}

\section{Highlights:}

Active male accelerate puberty onset.

Active male increase frequency of estrus behavior.

Active male increase levels of estradiol and progesterone.

\begin{abstract}
The present study investigated the male effect on the estrus behaviors, estradiol and progesterone release in prepubertal Saanen goats. Twenty-nine female Saanen goats at $135 \pm 10$ days old with body weight of $22.8 \pm 3.3 \mathrm{Kg}$ were randomly assigned to three treatments: exposure to sexually active male (male treatment), exposure to androgenized females (androgenized female treatment), and prepubertal goats isolated from active male and androgenized females (control treatment). Sexual behaviors associated with estrus were recorded daily, and blood samples were taken weekly to determine estradiol and progesterone concentrations over 24 weeks. The experimental goats subjected to male or androgenized female had significantly higher frequency of estrus (mount acceptance) $(\mathrm{P} \leq 0,02)$, progesterone $(\mathrm{P} \leq$ $0,01)$, and estradiol $(\mathrm{P} \leq 0,01)$ release than the control goats. Furthermore, goats exposed to a male showed estrus behavior two weeks earlier and maintained this estrus behavior for three weeks more than goats of both female and control treatments. Estrus was observed in $70 \%$ of goats in male and female treatments during the breeding season versus $44 \%$ of the control goats. Finally, significantly more goats subjected to male treatment (60\% of goats) showed progesterone concentrations higher than $1 \mathrm{ng}$ $\mathrm{mL}^{-1}$ (which indicates the presence of a functional corpus luteum) compared to the female and control treatment (40 and $22 \%$ of goats, respectively). These results shows that male treatment significantly increased the number of females showing estrus behavior, estradiol and progesterone release, and the number of animals with a functional corpus luteum, anticipating puberty for experimental goats, suggesting that the male effect could be used to anticipate the onset of puberty in goats.
\end{abstract}

Key words: Male effect. Hormone. Corpus luteum. Goats.

\footnotetext{
${ }^{1}$ Discentes do Curso de Mestrado ou Doutorado do Programa de Pós-Graduação em Nome do Curso, Faculdade de Zootecnia e Engenharia de Alimentos, FZEA, Pirassununga, SP, Brasil. E-mails: laurinda.augusto@uem.mz; alicedeleo@yahoo.com.br; gfacholi@hotmail.com

2 Pesquisadores, Faculdade de Zootecnia e Engenharia de Alimentos, FZEA, Pirassununga, SP, Brasil. E-mails: gkrempel@usp.br; sandoliv@usp.br

3 Prof., Faculdade de Zootecnia e Engenharia de Alimentos, FZEA, Pirassununga, SP, Brasil. E-mail: jnegrao@usp.br

Author for correspondence
} 


\section{Resumo}

O presente estudo investigou o efeito do macho sobre o comportamento do estro, liberação de estradiol e progesterona em cabritas Sannen pré-púberes. Vinte e nove cabritas com $135 \pm 10$ dias de idade e peso corporal de 22,8 $\pm 3,3 \mathrm{~kg}$ foram submetidas à três tratamentos: macho; fêmeas androgenizadas; controle (mantidas isoladas do efeito macho ou de fêmeas androgenizadas). Os comportamentos sexuais foram registrados diariamente e as amostras de sangue foram colhidas semanalmente ao longo de 24 semanas. Os tratamentos macho e fêmea androgenizada aumentaram significativamente a ocorrência comportamental do estro $(P \leq 0,02)$, a concentração de progesterona $(P \leq 0,01)$ e estradiol $(P \leq 0,01)$ em comparação ao tratamento controle. As cabritas expostas ao efeito macho anteciparam o comportamento de estro em duas semanas, e o mantiveram por mais três semanas quando comparado às cabritas dos tratamentos fêmea androgenizada e controle. Apenas $44 \%$ das cabritas controle foram observadas em estro, sendo que $70 \%$ das cabritas submetidas aos tratamentos macho e fêmea androgenizada foram observadas em estro. Além disso, $60 \%$ das cabritas expostas ao efeito macho, $40 \%$ das cabritas expostas ao efeito fêmea androgenizada e $22 \%$ das cabritas controle apresentaram concentrações de progesterona superiores a $1 \mathrm{ng} \mathrm{mL}-1$, o que indica a presença de corpo lúteo funcional. De fato, o efeito macho aumentou significativamente o número de fêmeas em estro, a concentração de estradiol e progesterona, o número de fêmeas com corpo lúteo funcional, sugerindo que o efeito macho pode ser usado para antecipar o início da puberdade em cabritas Saanen.

Palavras-chave: Efeito macho. Hormônios. Corpo lúteo. Cabras.

\section{Introduction}

Puberty can be defined as the period when an animal develops the ability to reproduce. During this period, dairy ruminants shown an intense development of the ovaries, uterus and mammary glands, as well as their first sexual behaviors (Fatet, Pellicer-Rubio, \& Leboeuf, 2011). The process of puberty is regulated by a sequential hormonal changeover, and the synthesis of sex steroids by the ovaries is essential for complete development of the reproductive axis (Ebling, 2005; Foster, Jackson, \& Padmanabhan, 2006).

During the prepubertal period, estradiol synthesis by the ovaries stimulates gonadotropinreleasing hormone $(\mathrm{GnRH})$ and consequently a surge in luteinizing hormone (LH). This hormonal changeover precedes the first ovulation at puberty (Scaramuzzi \& Martin, 2008; Valasi, Chadio, Fthenakis, \& Amiridis, 2012). Estradiol triggers for both GnRH and LH changes in ruminants, and for the start of the estrus behavior, and the male effect appear to influence the synthesis and release of estradiol, GnRH, and LH (Foster et al., 2006; FabreNys \& Gelez, 2007).
The age at which animals reach puberty is also affected by environmental factors and social interactions and management (Scaramuzzi \& Martin, 2008; Fiol, Quintans, \& Ungerfeld, 2010). For goats and sheep, the interactions between males and females adults stimulate ovarian activity and synchronizes estrus during the breeding season (Scaramuzzi \& Martin, 2008; Delgadillo et al., 2012). Furthermore, the male effect has also shown a potential to accelerate puberty in mouse and pigs (Evans \& O'doherty, 2001; Flanagan, Webb, \& Stowers, 2011). In anestrous goats, the immediate response to the male effect is associated with an increase in LH levels followed by ovulation (FabreNys \& Gelez, 2007; Delgadillo, 2011), and the male effect increases the reproductive efficiency of the herd (Scaramuzzi \& Martin, 2008; Valasi et al., 2012). The information concerning puberty onset on Saanen goats originated from temperate latitude, adapted during several generations to tropical latitude is scarce.

In fact, anticipate the onset of puberty of prepubertal goats can reduce the age at first calving, improving reproductive rate and maximizing milk 
yield during the productive life of goat. Thus, we tested the hypothesis that active male effect could be used as a management strategy to anticipate the start of puberty on Saanen prepubertal goats. In this context, the objective of this study is evaluate the effect of introduction of an active male or an androgenized female on the start of puberty, sexual behavior, estradiol and progesterone release in prepubertal Saanen goats.

\section{Materials and Methods}

All of the animal procedures were in compliance with the ethical procedures of the Faculty of Animal Science and Food Engineering (FZEA) of the University of Sao Paulo (USP), protocol number 2151210.

\section{Locations, animals, breeding season and diet}

The experiment was carried out at the Laboratory of Animal Physiology in Pirassununga, Brazil

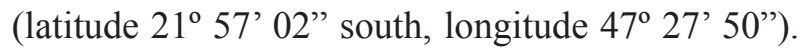
The climate in this area is subtropical with an average annual temperature of $23{ }^{\circ} \mathrm{C}$, humidity of $73 \%$ and annual rainfall varying from 1300 at 2000 $\mathrm{mm}$ (rainy season from November to March).

All prepubertal goats had free access to water and received a total diet (60:40 corn silage and mixed grain) to ensure ad libitum feeding. The total diet was formulated to satisfy all of the nutrients and energy requirements of the animals, and to promote a daily gain of $0.150 \mathrm{~kg}$ based on National Research Council [NRC] (2006) requirements for goats from May 8 to October 23 (experimental period). The total amount of diet that was offered and refused were weighed biweekly and feed intake was adjusted to result in $10 \%$ leftovers.

\section{Treatments}

At the beginning of the experiment (on May 8), the 29 goats kids were $135 \pm 10$ days old weighed
$22.8 \pm 3.3 \mathrm{~kg}$. At the end of experiment (on October 23 ), the goats were $303 \pm 10$ days old weighted $53.6 \pm 2.1 \mathrm{Kg}$. From May 8 to October 23, these homogenous prepubertal goats were randomly distributed into three treatments: 1) 10 goats were subjected to active male, male treatment; 2) 10 goats were subjected to androgenized female, androgenized female treatment; and 3) 9 control goats were isolated from male and androgenized female.

From May to October control group was isolated from contact with male and androgenized female in another experimental barn. The control goats could not see, smell and hear others groups. The other goats had daily physical contact with 2 males or 2 androgenized female (all sexually active) from 06h00 to $08 \mathrm{~h} 00$ hours throughout the experiment. During the remainder of the day, prepubertal goats exposed to male and androgenized female could smell, see, and hear respectively the male or androgenized female.

The androgenized females received intramuscular testosterone administration as follows: $300 \mathrm{mg}$ of testosterone during two consecutive days; $300 \mathrm{mg}$ of testosterone 5 days after the first application; and $300 \mathrm{mg}$ testosterone every 4 days until the end of the experiment (Mellado \& Hernadez, 1996).

\section{Behavioral observations}

On experimental farm adult Saanen goats and bucks show estrus behavior from April to October (breeding season). One week before the beginning of the experiment, the male and the androgenized female were exposed to adult goats on estrus to determine their sexual behavior. At this moment, the male and androgenized female were sexually active and exhibited the following behaviors: chasing, dominance, mounting, flehmen and urination during their contact with the goat on estrus.

From May to October, daily observations were recorded from $06 \mathrm{~h} 00$ to $08 \mathrm{~h} 00$ hours, individual 
behaviors associated with estrus of prepubertal goats were monitored as frequencies. These data were measured based on previous studies (Mellado \& Hernadez, 1996; Delgadillo et al., 2012). The following behavioral changes were monitored: vocalization, tail moving, mounting another prepubertal goats, being mounted, estrus (mount acceptance and immobilization). As suggested by Chemineau, Daveau, Maurice and Delgadillo, (1992), estrus behavior was scored each time that a prepubertal goat remained immobilized when mounted by another animal (male, androgenized female or other prebubertal goat). All details concerning the behaviors are described in Table 1.

Table 1

\section{Descriptions of each behavior recorded}

\begin{tabular}{ll}
\hline Variables & Description \\
\hline Vocalization & Scored each time that a prepubertal goat vocalized. \\
Tail moving & Scored when a prepubertal goat made fast and regular tail movements. \\
Mounting another prepubertal goat & Scored when a prepubertal goat mounted another prepubertal goats. \\
& Scored when a prepubertal goat was mounted by another animal (male, \\
Mounted by another animal & androgenized female or another prebubertal goat). \\
Estrus: mount & Scored when a prepubertal goat remained stop when mounted by another \\
acceptance & animal (male, androgenized female or another prebubertal goat). \\
\hline
\end{tabular}

Behaviors were recorded as 0 for an absence of observation or 1 for the occurrence of an observation. To avoid mistakes, one trained observer individually recorded each goat to differentiate the behaviors of estrus (immobilization and mount acceptance), mounting another goat, and being mounted by another animal.

\section{Estradiol and progesterone concentrations}

Blood samples were taken from all goats, just before the beginning of treatment (on May 8) and during the experimental treatment (from May 15 to October 23). Blood samples were collected of all experimental goats weekly at $09 \mathrm{~h} 00$ hours from the jugular vein in heparinized tubes and placed on ice immediately after sampling. Afterwards, the blood samples were centrifuged at $2100 \mathrm{~g}$ and $4{ }^{\circ} \mathrm{C}$ for 15 minutes, and plasma was stored at $-20{ }^{\circ} \mathrm{C}$ until the estradiol and progesterone analyses.

Progesterone concentration was measured by an ELISA kit (Monobind Inc., Lake Forest, CA, USA). The test has a sensitivity of $0.1 \mathrm{ng} \mathrm{mL}^{-1}$, and the intra- and inter-assay coefficients of variation were 3.1\% and $7.0 \%$, respectively. Estradiol concentration was also measured by an ELISA kit (Monobind Inc., Lake Forest, CA, USA). As suggested by the kit instructions, plasma samples were extracted and concentrated by a liquid-extraction method (diethyl ether and deionized water, 1:5). The test has a sensitivity of $1 \mathrm{pg} \mathrm{mL}^{-1}$, and the intra- and interassay coefficients of variation were $4.5 \%$ and $6.2 \%$, respectively.

\section{Statistical analyses}

The data were analyzed using the Statistical Analysis System [SAS] (2008) after verification of the normality of residuals according to the ShapiroWilk PROC univariate. The results were subjected to an analysis of variance by the MIXED procedure of SAS (2008), which separated the following as causes of variation: treatments (male, androgenized female or control), animal, date of sampling and the interaction between treatment and date of sampling. In the model, the treatment effect was considered fixed, and the effects of the date of sampling and 
the animals were considered random. Several error covariance structures were tested, and the one that best fit the data according to the Bayesian information criterion was used. When significant, the means were compared using Fisher's least significant difference test, and significance was tested at $\mathrm{P} \leq 0.05$.

\section{Results}

Before the beginning of treatments (on May 8), none of the 29 prepubertal goats showed sexual behavior. However, two weeks after the beginning of treatments (on May 22), the prepubertal goats displayed sexual behavior, which was observed from the last weeks of May to the first weeks of September (Figure 1-A). Similarly to sexual behavior, estradiol $\left(1.35 \pm 0.03 \mathrm{pg} \mathrm{mL}^{-1}\right)$ and progesterone $(0.27 \pm$ $0.04 \mathrm{ng} \mathrm{mL}^{-1}$ ) that were low on May 8 (before the beginning of the treatment), increased after the beginning of treatments to attempt highest estradiol concentration on June 5 (Figure 1-B), and highest progesterone concentration on June 12 (Figure 1-C). However, estradiol and progesterone release decreased from the last weeks of July to return at August to concentration measured on end May.

A

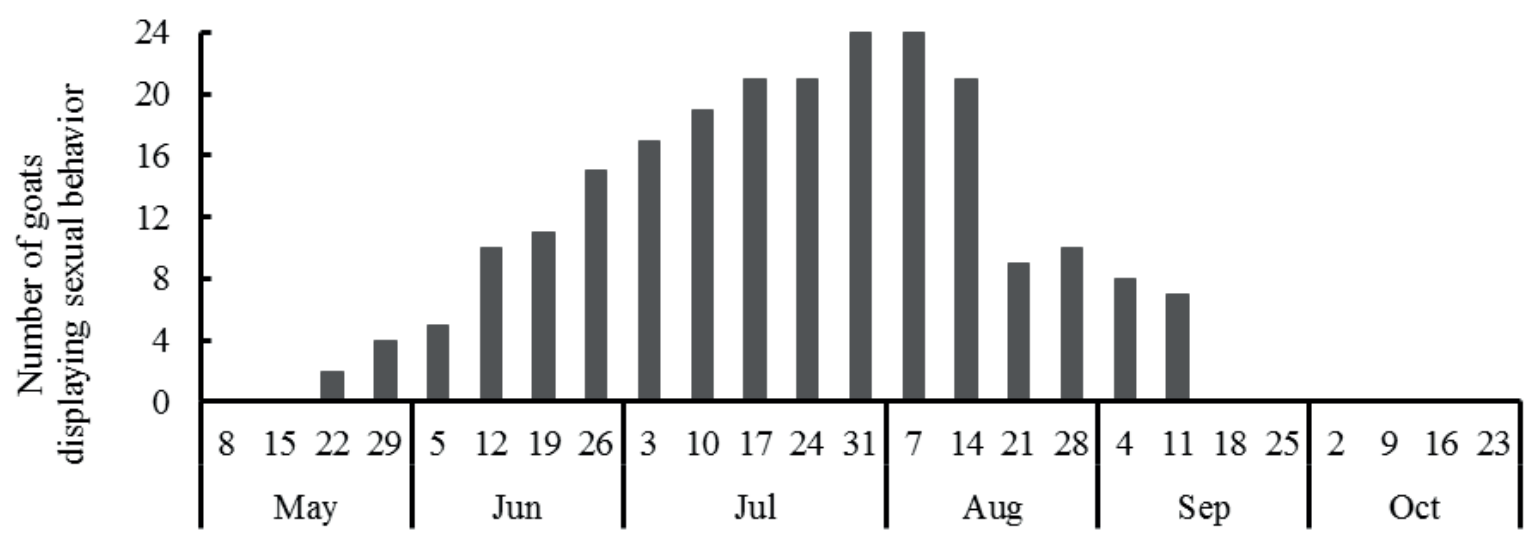

B

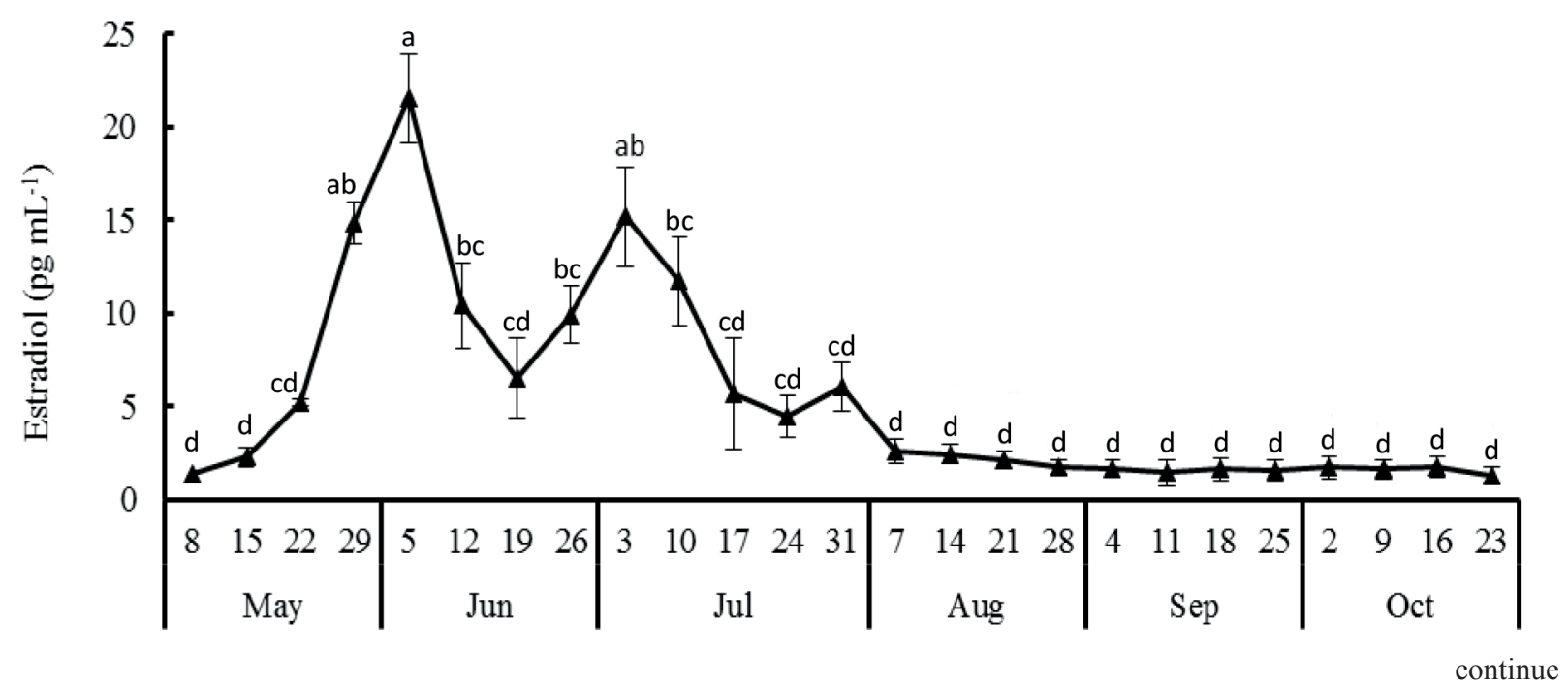


continuation

C

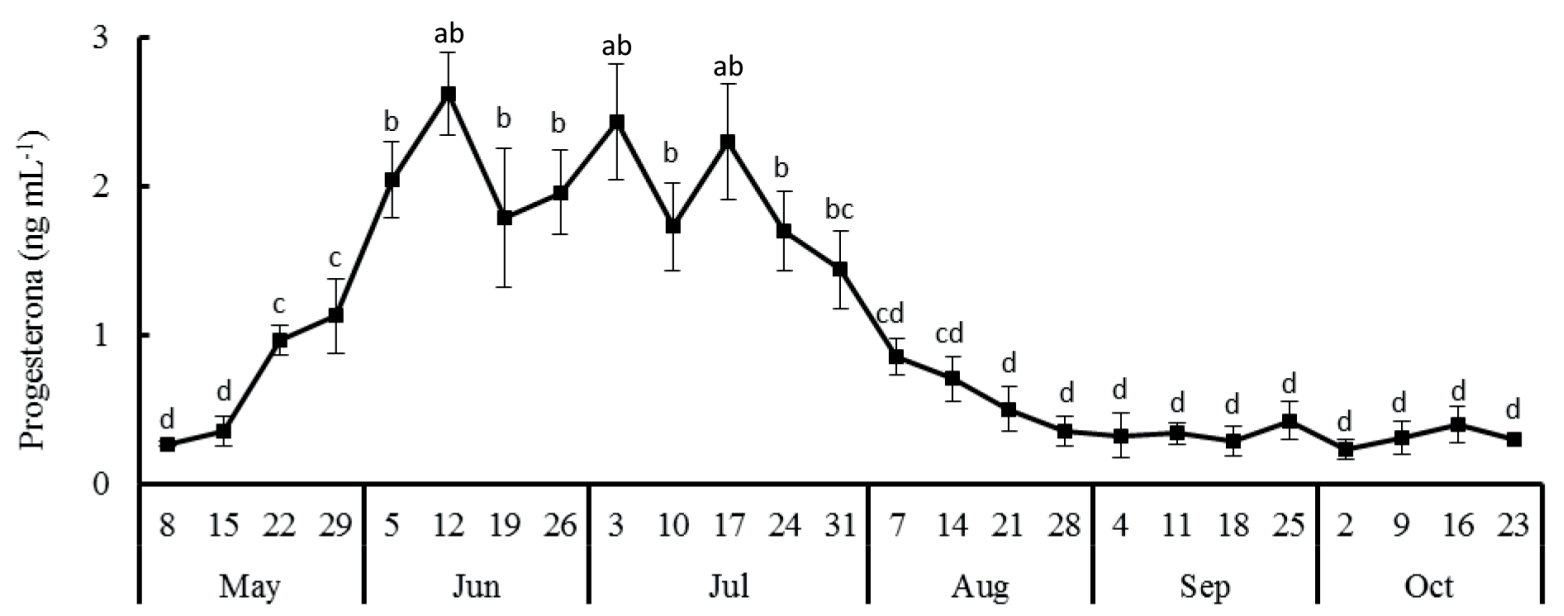

Figure 1. Percentage of goats displaying sexual behavior (A), progesterone (B) and estradiol (C) released by prepubertal goats during the entire experimental period (from May 8 to October 23). Means \pm sem with different letters differ significantly $(\mathrm{P} \leq 0.05)$.

As attempt, the body weight gain were similar to goats exposed to male, female and control treatments (Figure 2-A). However, from May 22 to September 11 (period that estrus behavior were observed), the goats exposed to a male had significantly higher frequencies of vocalization than the control goats (Figure 2-B). Indeed, the goats exposed to a male treatment had significantly higher frequencies of tail moving when compared to female and control treatments. Although, mounting behavior in the control treatment was significantly more frequent than in the male treatment. The goats exposed to a male or androgenized female had significantly higher frequencies of estrus (mount acceptance: scored when goat remained stop when mounted) than the control goats. There was no effect of treatments on instances of being mounted by another animal (Figure 2-C).

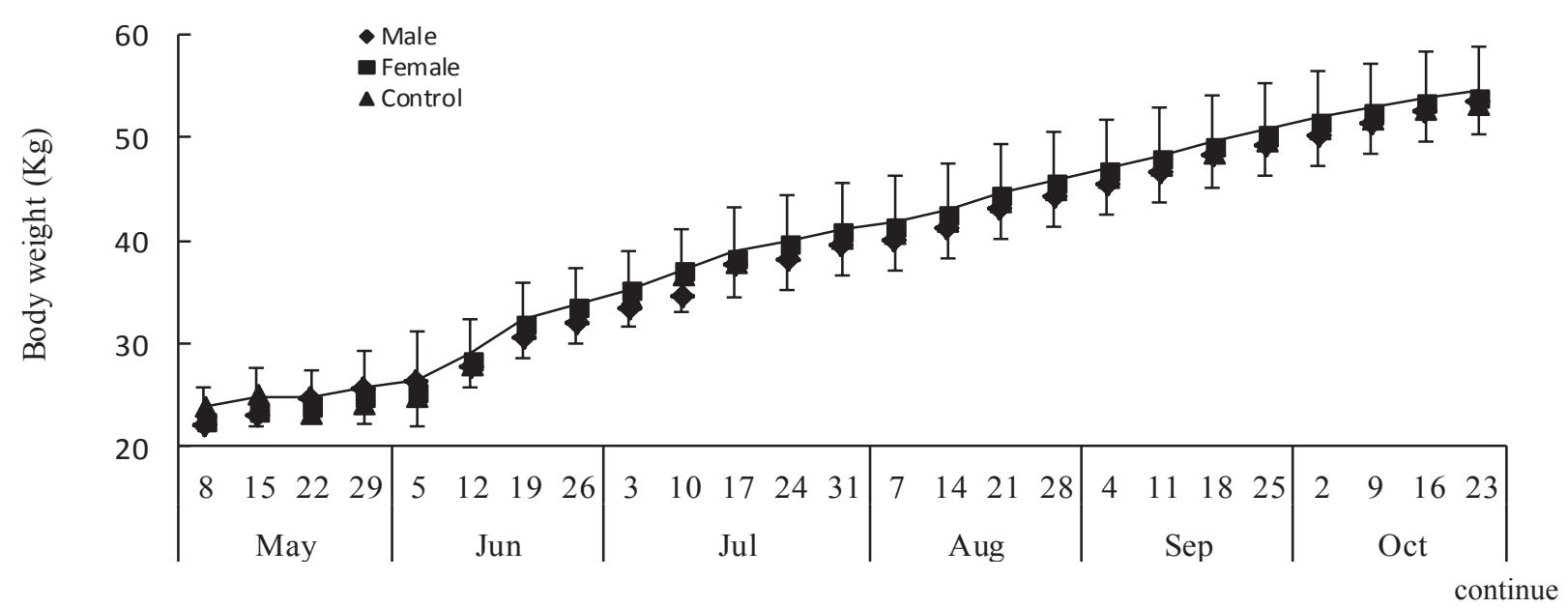


continuation

B

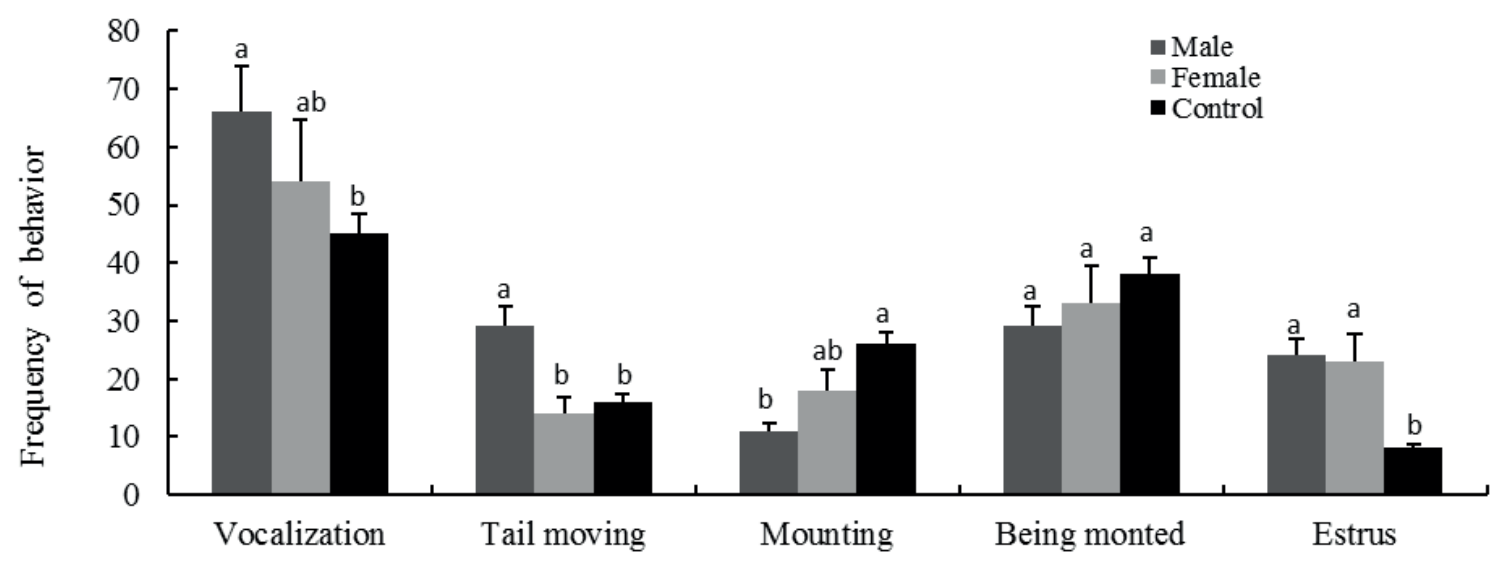

C

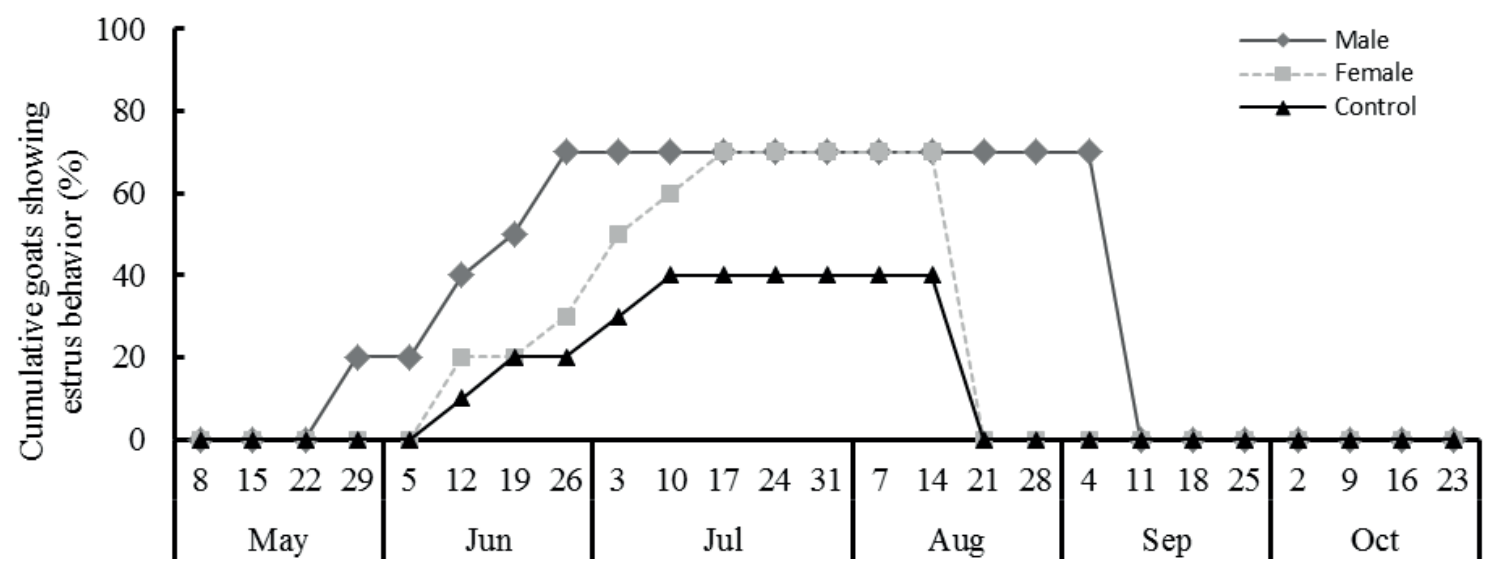

Figure 2. Body weight (A), frequency of each behavior recorded (B) and cumulative percentage of goats on estrus ( $\mathrm{C}$ - mount acceptance) exposed to a male, androgenized female, or control treatments during the entire experimental period (from May 8 to October 23). Means \pm sem with different letters differ significantly $(\mathrm{P} \leq 0.05)$.

Initially, the intervals between the first estrus observed in the present study were short (from 5 to 7 days), but the lengths increased during the breeding season to intervals of $18 \pm 3.5,22 \pm 3.0$ and $24 \pm 3.5$ days for the estrus cycles of the male, female and control treatments. The percentage of estrus behavior from May 22 to September 11 showed that goats exposed to male treatment had higher frequencies of estrus behavior than androgenized female and control treatment (Figure 2-B). Furthermore, prepubertal goats exposed to a male showed estrus behavior two weeks earlier and maintained this estrus behavior for three weeks more than androgenized female and control group (Figure 2-C). In fact, the cumulative percentage of goats displaying at least one estrus behavior was significantly higher for goats exposed to a male (70\%, 7 of 10 goats) and androgenized female (70\%, 7 of 10 goats) than the control group (44.4\%, 4 of 9 goats).

In the same period (from May 22 to September $11)$, there was a significant influence of treatments $(\mathrm{P}=0.01)$ on estradiol and progesterone 
concentrations (Figures 3-A and 3-B, respectively). Goats exposed to a male or androgenized female presented higher estradiol concentration than control goats. Thus, goats exposed to male treatment presented significantly higher progesterone concentrations than goats of androgenized female and control treatments. Furthermore, the percentage of prepubertal goats showing progesterone

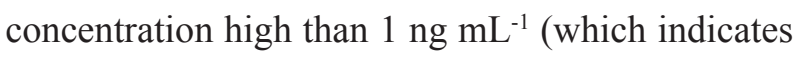
the presence of a functional corpus luteum) was significantly highest among the goats subjected to male ( $60 \%, 6$ of 10 goats) than goats female $(40 \%$, 4 of 10 goats) and control treatment (22\%, 2 of 9 goats) (Figure 3-C).
A

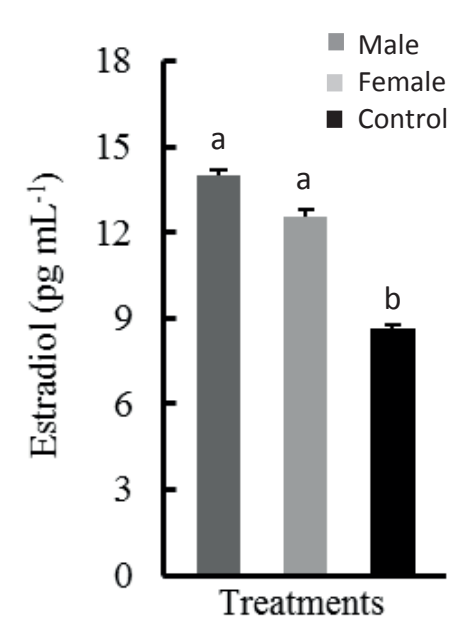

$\mathrm{B}$

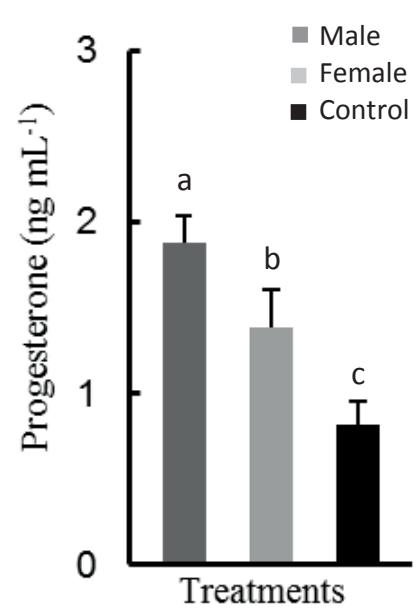

C

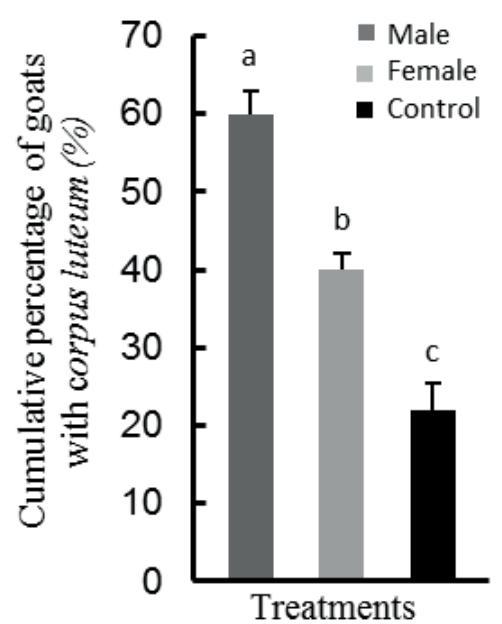

Figure 3. Estradiol (A) and progesterone release (B), and cumulative percentage of goats with a functional corpus luteum (C - considering progesterone $>1 \mathrm{ng} \mathrm{mL}^{-1}$ in plasma) among those exposed to a male, female, or control treatments from May 22 to September 11 (period of estrus behavior). Means \pm sem with different letters differ significantly $(\mathrm{P} \leq 0.05)$.

\section{Discussion}

Prepubertal goats did not display sexual behavior and their progesterone and estradiol concentrations were significantly lower before the beginning of treatments. However, the experimental goats submitted to treatments showed estrus behavior and high estradiol and progesterone from May 22 to September 11. These facts showed that there were relationships between the breeding season, sexual behavior, and progesterone and estradiol release in prepubertal Saanen goats, as previously reported for seasonal breeds at subtropical latitudes (Cruz, Rondina, \& Freitas, 2005; Duarte, Flores, Malpaux, \& Delgadillo, 2008; Nogueira, Cavalieri, Gummow, \& Parker, 2015). However, the present results indicated that the period of estrus behavior was short in the experimental goats in comparison to adult goats (Duarte et al., 2008; Nogueira et al., 2015). In fact, on the same farm and in the same environmental conditions, goats and bucks adults displayed estrous behavior from April to October.

In the present study, the first estrus behavior was observed two weeks after the beginning of the male effect. Similar delay was observed in the beginning of breeding season with adult goats when submitted to active male (Bedos et al., 2012, 2014). In contrast, other studies from a subtropical latitude with local goats argue that few a days of contact were enough to stimulate estrus behavior in adult goats (MartinezAlfaro et al., 2014; Ponce et al., 2015). Furthermore 
in the present study, the percentage of goats (that ranged from 44 to $70 \%$ ) displaying estrus behavior was lower than in adult goats at the beginning of the breeding season (higher than 90\%) (Bedos et al., 2014; Martinez-Alfaro et al., 2014; Ramirez et al., 2017). These results indicate that prepubertal goats need longer male stimulus to reach sexual and estrus behavior compared to adult goats.

Initially, the first estrus cycles observed were short and were 5 to 7 days long, but the duration length increased during the breeding season. At the end of breeding season, the goats exposed to the male had estrus interval of 18 days, while goats exposed to the androgenized female and the control treatments had estrus intervals of 22 and 24 days, respectively. This result indicate that the male effect extended the period of normal cycle length. Similar variations with a short cycle followed by a normal cycle were reported by previous studies that worked with the male effect (Chemineau, Pellicer-Rubio, Lassoued, Khaldi, \& Monniaux, 2006; Bedos et al., 2014; Ramirez et al., 2017). For this reason, the intervals between estrus observed in the present study were consistent with other studies (Menchaca \& Rubianes, 2001; Fatet et al., 2011; Delgadillo et al., 2012).

Previously, androgenized female was tested due low libido of bucks during the non-breeding season (Mellado \& Hernadez, 1996; Bedos et al., 2014), but in the present study androgenized female was also tested because a goat can maintain a longer or continue contact with a prepubertal goat group without any pregnancy risk, this management facilitates the use of artificial insemination to accelerate genetic progress of dairy goat breed. Although, $70 \%$ of goats exposed to male or androgenized female showed estrus versus 44 of control goats, the male treatment was more effectiveness to induce estrus behavior, estradiol and progesterone release than androgenized female and control treatments. Male treatment was more effectiveness probably due to their olfactory, auditory, visual and tactile stimuli (Mellado \&
Hernadez, 1996). In fact, in the present study goats submitted to male showed estrus behavior two weeks earlier and were observed on estrus during three weeks more than both androgenized female and control treatments. These five weeks supplementary and the intervals of 18 days for the estrus cycles to male treatment represent an interesting advance to reproductive management that can impact the productive performance of goats, because as suggested by other authors the male effect increases the reproductive efficiency of the herd (Foster et al., 2006; Scaramuzzi \& Martin, 2008).

In the present study goats exposed to male effect showed regular estrus, and higher estradiol and progesterone concentration. In fact, $60 \%$ of goats exposed to a male, $40 \%$ of goats exposed to androgenized female and $22 \%$ of goats exposed to control presented progesterone concentration higher than $1 \mathrm{ng} \mathrm{mL} \mathrm{mL}^{-1}$, which suggests that these experimental goats ovulated, had a functional corpus luteum and establish their cyclicity (Chemineau, Pellicer-Rubio, Lassoued, Khaldi, \& Monniaux, 2006; Blaszczyk, Udala, \& Gaczarzewicz, 2004; Katz, 2007). Consequently, it is possible argued that $60 \%$ of prepubertal goats submitted to male effect, $40 \%$ of goats submitted to female treatment and $22 \%$ of goats submitted to control treatments attempt their puberty during the present study.

\section{Conclusions}

Finally, male and androgenized female treatment significantly increased the frequency of estrus behavior, increased estradiol and progesterone release, and increased the percentage of goats reaching puberty early. This suggests that the male effect (active male or androgenized female) could be used as a management strategy to anticipate puberty in prepubertal goats. However, further studies must be performed with large bred to understand the variability between goats when submitted to male effect on puberty. 


\section{Acknowledgments}

This work was supported by Coordination for the Improvement of Higher Education Personnel (CAPES), National Counsel of Technological and Scientific Development (CNPq) and São Paulo Research Foundation (FAPESP).

\section{References}

Bedos, M., Duarte, G., Flores, J. A., Fitz-Rodriguez, G., Hernandez, H., Vielma, J.,... Delgadillo, J. A. (2014). Two or $24 \mathrm{~h}$ of daily contact with sexually active males results in different profiles of $\mathrm{LH}$ secretion that both lead to ovulation in anestrous goats. Domestic Animal Endocrinology, 48, 93-99. doi: 10.1016/j.domaniend.2014.02.003

Bedos, M., Velazquez, H., Fitz-Rodriguez, G., Flores, J. A., Hernandez, H., Duarte, G.,... Delgadillo, J. A. (2012). Sexually active bucks are able to stimulate three successive groups of females per day with a 4-hour period of contact. Physiology \& Behavior, 106(2), 259-263. doi: 10.1016/j. physbeh.2012.02.015

Blaszczyk, B., Udala, J., \& Gaczarzewicz, D. (2004). Changes in estradiol, progesterone, melatonin, prolactin and thyroxine concentrations in blood plasma of goats following induced oestrous in and outside the natural breeding season. Small Ruminant Research, 51(3), 209-219. doi: 10.1016/S09214488(03)00190-1

Chemineau, P., Pellicer-Rubio, M. T., Lassoued, N., Khaldi, G., \& Monniaux, D. (2006). Male-induced short oestrous and ovarian cycles in sheep and goats: a working hypothesis. Reproduction Nutrition Development, 46(4), 417-429. doi: 10.1051/ rnd:2006022

Chemineau, P., Daveau, A., Maurice, F., \& Delgadillo, J. A. (1992). Seasonality of estrus and ovulation is not modified by subjecting female alpine goats to a tropical photoperiod. Small Ruminant Research, 8(4), 299-312. doi: 10.1016/0921-4488(92)90211-L

Cruz, J. F., Rondina, D., \& Freitas, V. J. F. (2005). Ovarian follicular dynamics during anestrus in Anglo-Nubian and Saanen goats raised in tropical climate. Tropical Animal Health and Production, 37(5), 395-402. doi: 10.1007/s11250-005-4166-6

Delgadillo, J. A. (2011). Environmental and social cues can be used in combination to develop sustainable breeding techniques for goat reproduction in the subtropics. Animal, 5(1), 74-81. doi: 10.1017/ S1751731110001400

Delgadillo, J. A., Vielma, J., Hernandez, H., Flores, J. A., Duarte, G., Fernandez, I. G.,... Gelez, H. (2012). Male goat vocalizations stimulate the estrous behavior and LH secretion in anestrous goats that have been previously exposed to bucks. Hormones and Behavior, 62, 525-530. doi: 10.1016/j. yhbeh.2012.08.014

Duarte, G., Flores, J. A., Malpaux, B., \& Delgadillo, J. A. (2008). Reproductive seasonality in female goats adapted to a subtropical environment persists independently of food availability. Domestic Animal Endocrinology, 35(4), 362-370. doi: 10.1016/j. domaniend.2008.07.005

Ebling, F. J. P. (2005). The neuroendocrine timing of puberty. Reproduction, 129, 675-683. doi: 10.1530/ rep. 1.00367

Evans, A. C. O., \& O'doherty, J. V. (2001). Endocrine changes and management factors affecting puberty in gilts. Livestock Production Science, 68(1), 1-12. doi: 10.1016/S0301-6226(00)00202-5

Fabre-Nys, C., \& Gelez, H. (2007). Sexual behavior in ewes and other domestic ruminants. Hormones and Behavior, 52(1), 18-25. doi: 10.1016/j. yhbeh.2007.04.001

Fatet, A., Pellicer-Rubio, M. T., \& Leboeuf, B. (2011). Reproductive cycle of goats. Animal Reproduction Science, 124(3-4), 211-219. doi: 10.1016/j. anireprosci.2010.08.029

Fiol, C., Quintans, G., \& Ungerfeld, R. (2010). Response to biostimulation in peri-puberal beef heifers: influence of male-female proximity and heifer's initial body weight. Theriogenology, 74(4), 569-575. doi: 10.1016/j.theriogenology.2010.03.015

Flanagan, K. A., Webb, W., \& Stowers, L. (2011). Analysis of male pheromones that accelerate female reproductive organ development. Plos One, 6(2), 1-17. doi: 10.1371/journal.pone.0016660

Foster, D. L., Jackson, L. M., \& Padmanabhan, V. (2006). Programming of GnRH feedback controls timing puberty and adult reproductive activity. Molecular and Cellular Endocrinology, 254/255, 109-119. doi: 10.1016/j.mce.2006.04.004

Katz, L. S. (2007). Sexual behavior of domesticated ruminants. Hormones and Behavior, 52(1), 56-63. doi: 10.1016/j.yhbeh.2007.03.012 
Martinez-Alfaro, J. C., Hernandez, H., Flores, J. A., Duarte, G., Fitz-Rodriguez, G., Fernandez, I. G.,... Delgadillo, J. A. (2014). Importance of intense male sexual behavior for inducing the preovulatory LH surge and ovulation in seasonally anovulatory female goats. Theriogenology, 82(7), 1028-1035. doi: 10.1016/j.theriogenology. 2014.07.024

Mellado, M., \& Hernandez, J. R. (1996). Ability of androgenized goat wethers and does to induce estrus in goats under extensive conditions during anestrus and breeding seasons. Small Ruminant Research, 23(1), 37-42. doi: 10.1016/S0921-4488(96)00897-8

Menchaca, A., \& Rubianes, E. (2001).Effect of high progesterone concentrations during the early luteal phase on the length of the ovulatory cycle of goats. Animal Reproduction Science, 68(1-2), 69-76. doi: 10.1016/S0378-4320(01)00139-7

National Research Council (2007). Nutrients requirements of small ruminant: sheep, goats, cervids and new world camelids. Washington, D.C: National Academy Press.

Nogueira, D. M., Cavalieri, J., Gummow, B., \& Parker, A. J. (2015). Comparison of follicular dynamics and hormone profiles in Boer goats examined during the breeding and non-breeding seasons in the tropics of Queensland, Australia. Small Ruminant Research, 125,93-100. doi: 10.1016/j.smallrumres.2015.02.014
Ponce, J. L., Hernandez, H., Flores, J. A., Matthieu, K., Chemineau, P., \& Delgadillo, J. A. (2015). One day of contact with photostimulated bucks is sufficient to induce ovulation in seasonally anestrous goats. Theriogenology, 84(6), 880-886. doi: 10.1016/j. theriogenology.2015.05.019

Ramirez, S., Bedos, M., Chasles, M., Hernández, H., Flores, J.A., Vielma, J.,... Delgadillo, J. A. (2017). Fifteen minutes of daily contact with sexually active male induces ovulation but delays its timing in seasonally anestrous goats. Theriogenology, 87, 148153. doi: 10.1016/j.theriogenology.2016.08.019

Scaramuzzi, R. J., \& Martin, G. B. (2008).The importance of interactions among nutrition, seasonality and socio-sexual factors in the development of hormonefree methods for controlling fertility. Reproduction in Domestic Animals, 43(Suppl. 2), 129-136. doi: 10.1111/j.1439-0531.2008.01152.x

Statistical Analysis System Institute (2008). SAS Institute. SAS/STAT 9.2 User's Guide. Cary: SAS Institute Inc.

Valasi, I., Chadio, S., Fthenakis, G. C., \& Amiridis, G. S. (2012). Management of pre-pubertal small ruminants: Physiological basis and clinical approach. Animal Reproduction Science, 130(3-4), 126-134. doi: 10.1016/j.anireprosci.2012.01.005 
